\title{
Biogas potential of the black sea region from kitchen waste
} Karadeniz bölgesinin mutfak atıklarının biyogaz potansiyeli

\author{
Halil ŞENOL 1* $^{*}$ \\ ${ }^{1}$ Department of Genetics and Bioengineering, Faculty of Engineering, Giresun University, Giresun, Turkey. \\ halil.senol@giresun.edu.tr
}

\begin{abstract}
Today, energy demand has become one of the important problems. The rapid growth of the world population and the development of the industry have increased the need for energy. The vast majority of the world's energy needs come from natural energy sources. But the limited availability of these energy sources has led people to search for renewable energy sources. One of these renewable energy sources is biogas energy. Biogas is a gas mixture of organic substances formed by anaerobic microorganisms under anaerobic conditions at certain temperature conditions. It is flammable due to the presence of methane $\left(\mathrm{CH}_{4}\right)$ gas in average $65 \%$ by volume in the biogas. Other gases outside the methane in the biogas are undesirable gases. Biogas purified from unwanted gasses is the natural gas used today. Biogas production gains importance in terms of disposal of organic materials. Black Sea Region in our country, due to the disadvantage of the geographical location and the lack of settlements has been very difficult to store the landfill. Biogas production in the Black Sea Region is gaining importance in terms of eliminating these wastes and obtaining energy. In this study, biogas potential of kitchen wastes of provinces in Black Sea Region was determined. The highest biogas potential of the Black Sea Region was found to be $51163.20 \mathrm{~m}^{3}$ / day in Samsun province. The biogas potential of the kitchen wastes in the Black Sea Region was $296015.18 \mathrm{~m}^{3} /$ day.
\end{abstract}

Keywords: Biogas potential, Blacksea region, Kitchen wastes.

\begin{abstract}
Öz
Günümüzde enerji ihtiyacı önemli problemlerden biri haline gelmiștir. Dünya nüfusunun hızlı artıșı ve sanayinin gelișmesi enerji ihtiyacını artırmıştır. Dünya enerji ihtiyacının büyük çoğunluğu doğal enerji kaynaklarından sağlamaktadır. Fakat bu enerji kaynaklarının sinırlı olması insanları yenilenebilir enerji kaynakları arayışı içerisine sokmuștur. Bu yenilenebilir enerji kaynaklarından biri de biyogaz enerjisidir. Biyogaz, organik maddelerin oksijensiz ortamda belirli sicaklık şartlarında, anaerobik mikroorganizmalar sayesinde oluşan bir gaz karışımıdır. Biyogaz içerisinde hacimsel olarak ortalama \%65 oranında metan ( $\mathrm{CH}_{4}$ ) gazı bulunmasından dolayı yanıcıdır. Biyogazın içeriğindeki metan dıșındaki diğer gazlar istenmeyen gazlardır. Ístenmeyen gazlardan arıtılmış biyogaz günümüzde kullanılan doğal gazın yerini tutmaktadır. Biyogaz üretimi organik maddelerin bertaraf edilmesi açısından önem kazanmaktadır. Ülkemizde Karadeniz Bölgesi, coğrafi konumunun oluşturduğu dezavantajı ve yerleșim yerlerinin az olması nedeniyle mutfak çöplerini depolamak çok zor hale gelmiştir. Karadeniz Bölgesinde biyogaz üretimi bu mutfak atılarının giderilmesi ve enerji elde edilmesi açısından önem kazanmaktadır. Bu çalışmada Karadeniz Bölgesindeki illerin mutfak atıklarından olușabilecek biyogaz potansiyeli belirlenmiștir. Karadeniz Bölgesinin en fazla biyogaz potansiyeli $51163.20 \mathrm{~m}^{3} /$ gün olarak Samsun iline ait olduğu bulunmuștur. Karadeniz Bölgesinin mutfak atıklarından üretilebilecek biyogaz potansiyeli ise $296015.18 \mathrm{~m}^{3} /$ gün olarak bulunmuștur.
\end{abstract}

Anahtar kelimeler: Biyogaz potansiyeli, Karadeniz bölgesi, Mutfak atıkları.

consumption is increasing. For this reason, our country should be directed to different energy sources. An alternative source to these different energy sources is biogas. Our country has a very favorable and rich source for biogas production.

Our country is among the developing countries as it is in many countries. One of the basic requirements for achieving the level of developed countries is to produce our own energy. But the increasing energy shortage in our country affects the development of the country negatively. The world supplies the vast majority of its energy needs from natural energy fuels and from fossil fuels. But these fuels are about to run out because they are limited in nature. Since world energy needs increase by an average of $5 \%$ each year and a large proportion of the energy source used is natural energy sources, the world countries have searched for new energy sources [1],[2].

In terms of renewable energy sources, our country has great potential. Among these energy sources, biogas is one of the energies that have a very high potential in our country [3]. The energy need of our country is rapidly increasing due to rapid economic and industrial development. Energy need of Turkey will be doubled between 2000 and 2010 and five times bigger between 2000 and 2015 [3]. This proves that energy

Biogas; It is a mixture of odorless, colorless and flammable gas which can be produced from oxygen, anaerobic environment from human, animal and plant organic wastes. Biogas is not a pure gas. It contains $55-70 \%$ methane $\left(\mathrm{CH}_{4}\right), 30-40 \%$ carbon dioxide $\left(\mathrm{CO}_{2}\right), 1-5 \%$ hydrogen sulphide $\left(\mathrm{H}_{2} \mathrm{~S}\right)$ and traces of oxygen $\left(\mathrm{O}_{2}\right)$, carbon monoxide $(\mathrm{CO})$, nitrogen $\left(\mathrm{N}_{2}\right)$, hydrogen $\left(\mathrm{H}_{2}\right)$ gases. The thermal value of the biogas is 4 700-6 $000 \mathrm{kcal} / \mathrm{m}^{3}$ [4],[5]. Biogas attracts attention because it is a good fuel type due to the formation of clean energy and its thermal properties. Biogas is generally used in lighting, electricity generation, heating, internal combustion engines, etc. It can even be used in biogas-powered engines without any modification. The nature of the biogas is similar to that of its natural features [6]. Table 1 shows some properties of biogas

${ }^{*}$ Corresponding author/Yazışılan Yazar 
and other gases. If this table is examined it turns out that biogas is not very different from other flammable gases.

Table 1. Fuel values of some gases [15].

\begin{tabular}{ccc}
\hline Fuel type & $\begin{array}{c}\text { Heat value of } \\
\text { the fuel }(\mathrm{kJ} / \mathrm{kg})\end{array}$ & $\begin{array}{c}\text { Air / fuel ratio mixed } \\
\text { in the flue }(\mathrm{g} / \mathrm{g})\end{array}$ \\
\hline Methane gas & 50000 & 17.2 \\
Propane gas & 46300 & 15.6 \\
Butane gas & 45600 & 15.6 \\
Natural gas & 57500 & 17.0 \\
LPG & 46000 & 15.5 \\
Biogas & 18000 & 10.2 \\
(60\% methane) & & \\
\hline
\end{tabular}

\subsection{Biogas production microbiology}

Biogas is the formation of $\mathrm{CH}_{4}, \mathrm{CO}_{2}$ and some other gases by decaying organic substances in an oxygen-free environment under certain conditions, as indicated below. Biogas formed by the decomposition of organic materials in anaerobic environment is provided by mixed and various microbiological flora [7]. Microbiological decay consists of 3 different stages. These steps;

- Fermentation and Hydrolysis: Organic substances are broken down by hydrolytic and fermentative bacteria, forming acetic acid, volatile organic compounds and carbon dioxide,

- Acetic acid formation: A number of bacterial groups convert acetic acid to volatile fatty acids resulting from the fermentation and hydrolysis stages,

- Methane gas formation: The last stage of oxygen free fermentation. Methane bacteria at this stage convert products formed in the course of acetic acid formation into products such as methane, carbon dioxide and water [8]. Biogas formation is completed at the end of this phase.

Biogas production in terms of the installation of biogas plants varies according to the intended purpose. Biogas plants also vary according to their capacity. Those with a capacity of 6-12 $\mathrm{m}^{3}$ are called family type, $50-150 \mathrm{~m}^{3}$ with a capacity of farm type, and those with a capacity of $100-200 \mathrm{~m}^{3}$ are called village type biogas plant. However, countries such as Germany, Denmark, Sweden and the United States use higher capacity industrial biogas plants of $1000-10000 \mathrm{~m}^{3}$ [8]. Biogas production is now widely used in urban wastewater treatment plants and increasingly to eliminate organic wastes such as agricultural wastes, animal wastes [9]. Generally in biogas plants, the produced gas is converted directly into electricity by means of a generator. In Figure 1 this is implicitly expressed.

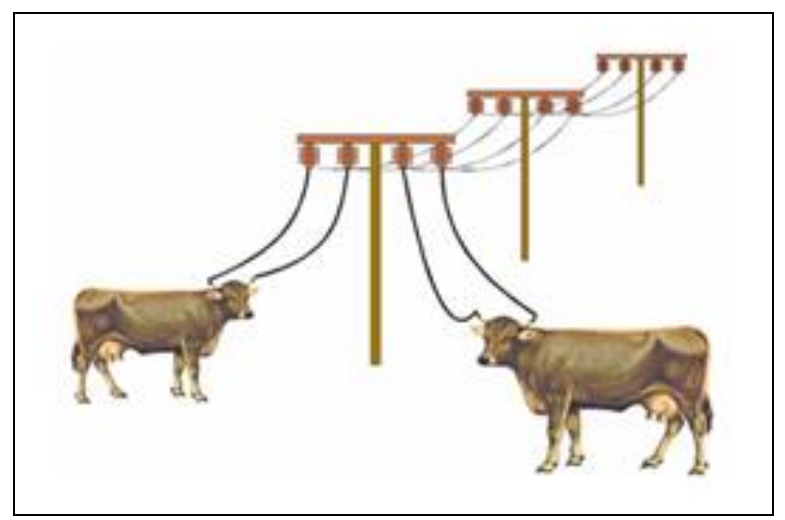

Figure 1. Energy production from organic waste [26].
Plant yield during biogas production; Several components such as $\mathrm{C} / \mathrm{N}$ ratio, mixing speed, $\mathrm{pH}$, temperature, loading rate, toxic substances and waiting time in the reactor are affected. The values of these components vary depending on the structure of the plant [10].

Biogas can be used as a result of small changes in the lighting, heating, electric energy production, without any special equipment for use in production of electricity [11]. When biogas is mixed with air at a ratio of $1 / 7$, combustion is fully realized [12]. At the same time, biogas can be used directly for heating in furnaces and hearths, as well as biogas in thermosiphons and water heaters. The biogas needs to be increased by about 2.5-3 times the diameter of the nozzle for combustion in LPG furnaces and water heaters [12].

According to Alçiçek and Demiruluş (1994), the amount of biogas needed for cooking purposes is $0.3 \mathrm{~m}^{3}$ per person per day. The amount of heat provided by $1 \mathrm{~m}^{3}$ of biogas equals 0.62 liters of gasoline, $1.46 \mathrm{~kg}$ of wood carpets, $3.48 \mathrm{~kg}$ of ozone, $0.43 \mathrm{~kg}$ of butane gas, $12.4 \mathrm{~kg}$ of artillery, $1.18 \mathrm{~m}^{3}$ of gasoline, 1 liter of alcohol, 0.8 liters of benzene [13].

Anaerobic bacteria require $20 \%$ less nitrogen and phosphorus than aerobic bacteria. In anaerobic processes, chemical oxygen demand (COD) is often used instead of carbon. Likewise, total organic carbon (TOC) can also pass. COD: N: P ratio is defined for anaerobic processes. This ratio should be 100: 2: 0.2 . This ratio can be taken as 1000: 5: 1 for low yield and 350: 5: 1 for high yield [14].

Table 1 shows the thermal value of biogas and similar gases. The thermal value of $1 \mathrm{~kg}$ of biogas with $60 \%$ methane gas is $18.000 \mathrm{~kJ}$.

The most important nutrients in the anaerobic fermentation process are nitrogen, carbon and phosphorus compounds. Besides these, the methanogens need copper, zinc, cobalt, nickel, iron, magnesium, calcium, potassium, sulfur and vitamins. In animal wastes, the medium is suitable. However, in some vegetal wastes or systems produced from domestic wastes, additional nutrient medium may be needed [16]. Although hydrolytic bacteria are not greatly affected by deficiencies in the nutrient media, methanogen bacteria can be affected even by a lack of nutrients [17]. In anaerobic fermentation, the amount of some mineral substances affects anaerobic bacteria. In Table 2 , some anaerobic microorganisms have been given inhibition levels for anaerobic fermentation [18].

Table 2. Toxic value limits of some minerals in anaerobic fermentation.

\begin{tabular}{cc}
\hline $\begin{array}{c}\text { Anaerobic process inhibiting } \\
\text { minerals }\end{array}$ & $\begin{array}{c}\text { Blocking levels } \\
(\mathrm{mg} / \mathrm{L})\end{array}$ \\
\hline Sodium $\left(\mathrm{Na}^{+}\right)$ & $3500-60000$ \\
Sodium chloride $(\mathrm{NaCl})$ & 40000 \\
Sulphate $\left(\mathrm{SO}^{2-}\right)$ & 5000 \\
Copper $\left(\mathrm{Cu}^{2+}\right)$ & $100-300$ \\
Nitrate $(\mathrm{N})$ & 0.05 \\
Magnesium $\left(\mathrm{Mg}^{2+}\right)$ & $1000-2400$ \\
\hline
\end{tabular}

The rate of formation of biogas from the fermenter and the ratio of $\mathrm{CO}_{2} / \mathrm{CH}_{4}$ in the biogas alkaline and $\mathrm{pH}$ are important. The acidity of the mixture in the fermenter is defined as the amount of acid required to make the $\mathrm{pH} 4$. The higher the value of the alkalinity value, the higher the cushioning power of the system. A decrease in the alkalinity value or an increase in the amount 
of carbon dioxide in the gas is a measure of the degradation of the anaerobic process equilibrium prior to the fall of $\mathrm{pH}$ [19]. For anaerobic fermentation, the range of $1000-5000 \mathrm{CaCO}_{3}$ $\mathrm{mg} / \mathrm{L}$ is sufficient for anaerobic fermentation [20].

The $\mathrm{pH}$ range suitable for methanogens is 6.8 to 7.2 [21]. The decrease of $\mathrm{pH}$ below 6.6 significantly reduces methanogen activity. While a decrease of 6.2 means toxic effect. Acid production continues at this $\mathrm{pH}$ and yields continue until the acid bacteria have a pH value of 4.5-5.0 [22]

At the beginning of anaerobic fermentation, the pH level has been reported to decrease by up to 6 . This is due to the acidification phase. The methanogens is then counterbalanced at 7-7.5, increasing the $\mathrm{pH}$ level in parallel with the increase in ammonia concentration [23]. In anaerobic systems, if the $\mathrm{pH}$ value falls below 7 , lime or ash may be added to bring the $\mathrm{pH}$ to equilibrium, but acid addition should not be done when the $\mathrm{pH}$ is above 7. Because, $\mathrm{H}_{2} \mathrm{~S}$ accumulation can increase in the nature [24].

In Figure 2, the combustion of biogas is given visually. This color is a bright blue color. At some burns, this blue color starts to form in flames like yellow and red. This event proves that water vapor is in the biogas.

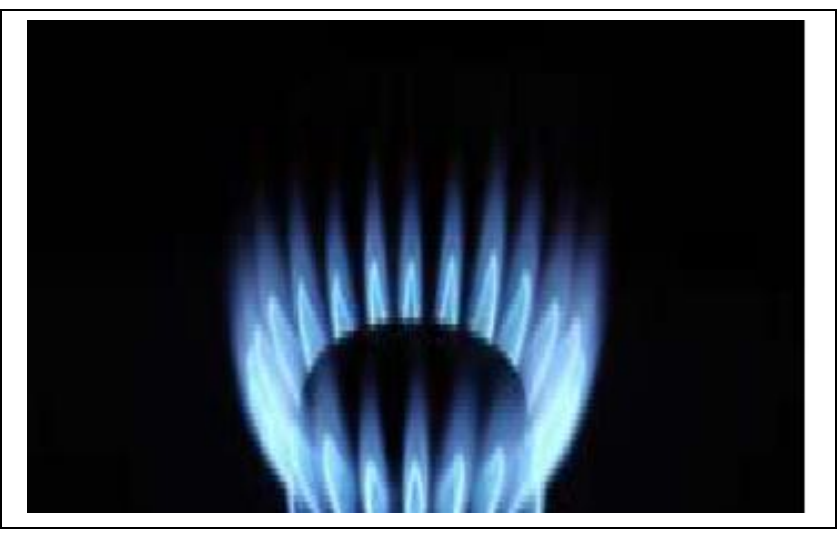

Figure 2. Biogas flame [1].

In Figure 3, an example of using biogas for heating in the greenhouse sector is given. Thus, biogas burning in the greenhouse is beneficial for plants both in terms of carbon dioxide and heat.

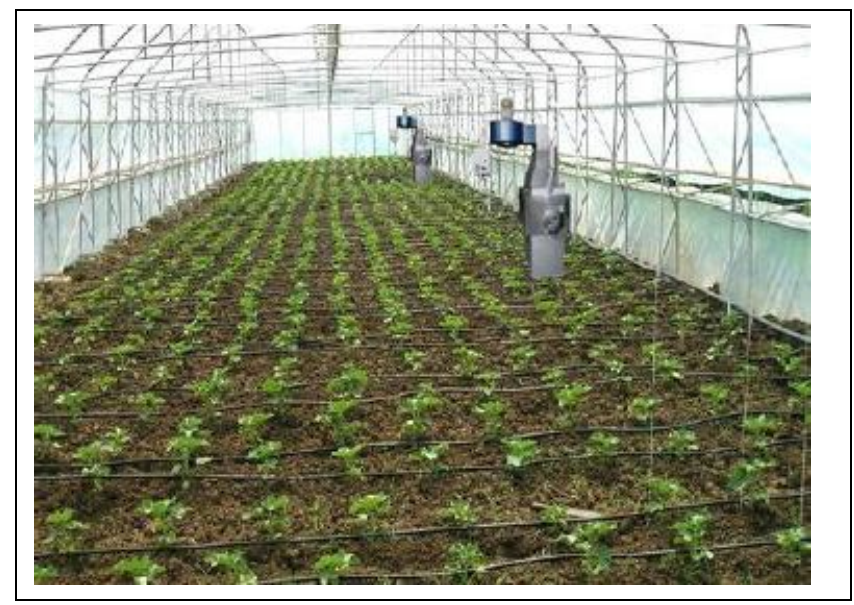

Figure 3. Biogas used for heating in the greenhouses [2]

In term of climate change, rapid economic growth in Turkey, due to industrialization and urbanization of experienced environmental pressures, new regulations are implemented. Growth is in line with a 6\% increase in annual primary energy demand and a $125 \%$ increase in $\mathrm{CO}_{2}$ equivalent emissions from 1990 to 2014. In addition, a rapid increase in population and Turkey has urbanization. Share of urban population in total population Increased from 70.7 to 73.4 million from 2010 to 2015 , urbanization rate increased by $1.97 \%$ in the same period. The urbanized population is expected to reach 71 million by 2023. The negative impact of climate change adds to these challenges and calls for efforts that can effectively tackle related problem [25].

The most biogas/methane producing substances are organic fats, proteins and carbohydrates, respectively. Proteins and oils cause high methane content, while oxidized components such as sugars causes low methane content. During fermentation, carbohydrates change by about $13 \%$, proteins by $36 \%$ and fats by about $76 \%$. Proteins and oils can ferment longer than carbohydrates. The cellulosic fermentation lasts several weeks. Hemicellulose, fat and protein are fermented for several days, sugar, volatile fatty acids and alcohol in a few hours. Biogas can be obtained by placing different materials in the feed material. For example, it has been observed that when the feed material is mixed with charcoal, the yield is increased by $17 \%$ while producing biogas from cattle manure. To accelerate bacterial activation in the same way, saponify steroid materials obtained from plants are also used to increase biogas yield. Increase biogas production by adding glycerin provided that the anaerobic fermentation of protein dense materials does not exceed 6\%. Likewise, it has been reported that adding calcium to feed material up to $3 \mathrm{~g} / \mathrm{L}$ improves biogas yield but slows production at high rates, such as $5-7 \mathrm{~g} / \mathrm{L}$, when raw materials such as pork waste with high fat content are studied [26]. Efficiency in biogas systems is calculated using four approaches. In the first approach, the daily biogas yield per reactor volume is taken into account. Secondly, the amount of methane contained in the biogas obtained is important. Thirdly, it is considered how much $\mathrm{m}^{3}$ of biomass is obtained per $\mathrm{kg}$-VS (volatile solid) or kg-COD of feed material. Finally, it is the criterion based on kg-VS or kg-COD, which eliminates the feed material. Gas production amount is $0.45 \mathrm{~m}^{3} / \mathrm{kg}-\mathrm{VS}$, VS removal rate is $0.54 \mathrm{~kg} . \mathrm{VS} / \mathrm{kg} . \mathrm{VS}$. The most efficient anaerobic reactor is $2.5 \mathrm{~m}^{3}$ of biogas/day [27].

The biogas potential calculation is important in terms of energy recovery and waste disposal. In a study, determined the biogas potential of Ardahan city to be produced from animal wastes and an annual energy value of $322.6 \mathrm{GWh}$ of organic waste was determined [28]. In recent years, studies revealed that biomass energy potential is $9.5 \mathrm{GW}$ in Turkey [29]. In the study which is done in Erdil and Erbiyık, it has defended that Turkey has rich biomass energy and this biomass energy potential will be evaluated [30]. In another study, Turkey's renewable and yearly energy potential of biomass was estimated at respectively 17.2 and 32.6 Mtoe [31]. In 2018, in a study Turkey's biogas potential of cattle manure 107.8 PJ/year, biogas potential of chicken manure $36.5 \mathrm{PJ} /$ year, while the biogas potential of agricultural waste $305.3 \mathrm{PJ} /$ year that was reported [32]. Here, it is emphasized that Turkey is a significant amount of energy by plants in addition to animal manure. Senol reported the biogas potential of hazelnut wastes in Giresun province as $3176636 \mathrm{~m}^{3}$ /year in 2019 [33]. In 2011, it was emphasized that Turkey's existing biogas potential of $49 \mathrm{PJ}$. $68 \%$ of this potential has been reported to be cattle manure, $5 \%$ sheep and $27 \%$ chicken manure [3]. In one study, Turkey's total 
biogas potential of municipal solid waste, energy crops, animal manure and wastewater sewage sludge have been determined as 188.21 TWh / year [29]. Gürdi and Karaca [34] found the biogas potential of Samsun City to be $135 \mathrm{GWh} /$ year. Goktas et al. [35] the biogas potential of Kırıkkale City from cattle manure was 91.8 MWh/year, while Öztürk and Kılıçkan [36] found that the biogas potential of Aydın's plant and animal wastes was 13 $\mathrm{PJ} /$ year in 2016. Turkey has often emphasized in the literature that has great potential in terms of renewable energy. In theory, however, this potential needs to be studied more specifically in practice. That is, specifying the country's potential can only raise awareness of energy savings, but the biogas plant needs to exist only where the energy potential is high. Therefore, biogas potentials should be determined as regions or provinces.

The aim of this study was to emphasize the biogas potential of kitchen wastes of the Black Sea region, which was omitted in the literature. In our country, Black Sea Region is very inadequate in terms of disposal of Kitchen Waste. For this reason, the amount of waste in the Black Sea region and the biogas and electricity energy value that can be produced from these wastes are emphasized in this study.

\section{Material and method}

It was emphasized above that biogas can be produced from all organic materials. Our country has a great potential for urban solid wastes. The daily amount of solid waste per capita in our country is approximately $1.2 \mathrm{~kg}$. $60 \%$ of these wastes are organic wastes and $34 \%$ are kitchen wastes [33]. In Figure 4, the $\%$ distribution of these wastes is given in detail. For this reason, the evaluation of these wastes gains importance especially in the Black Sea Region because of the low storage areas of the garbage, the disposal of the garbage into the sea. Although $34 \%$ of municipal solid waste is kitchen waste, $60 \%$ is organic waste. Figure 4 shows the distribution of urban solid wastes by type [37],[38].

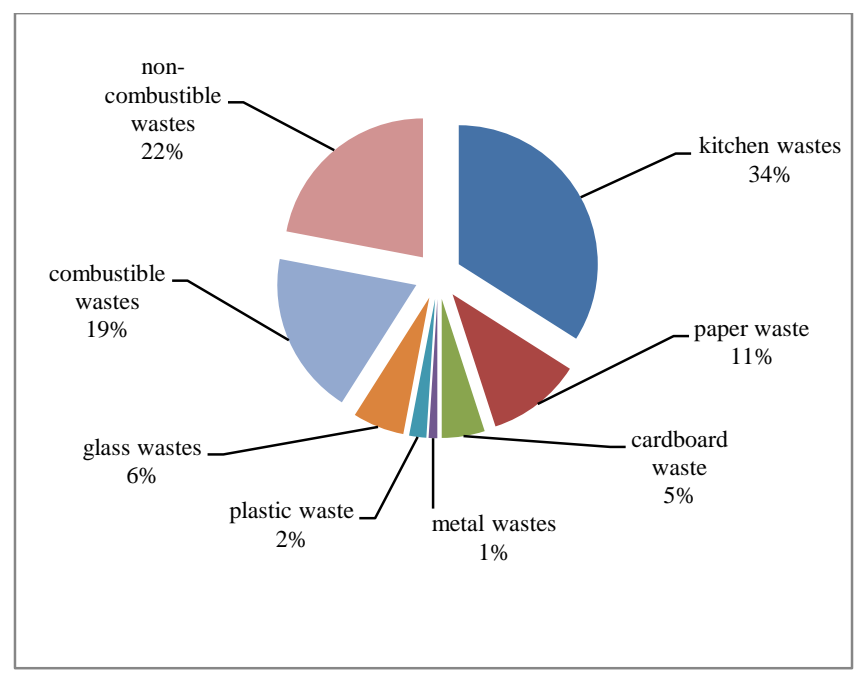

Figure 4. Percentage distribution of municipal solid waste by type.

In the Black Sea region; Artvin, Rize, Bayburt, Trabzon, Gümüşhane, Giresun, Ordu, Tokat, Samsun, Amasya, Çorum, Sinop, Kastamonu, Karabük, Bartın, Zonguldak, Bolu and Düzce. Kitchen waste collected mainly from the central and coastal areas does not have a regular landfill site because of the geographical location of these illusions, the mountains parallel to the seas and the absence of flat settlements. For this reason, it is important to dispose of garbage in our country especially in the Black Sea region. One of these disposal methods is biogas production. In terms of biogas production, our country is far behind other countries. The aims of preventing this pollution in the Black Sea cities are insufficient and air pollution is occurring. In some of these cases biogas plants have been established, but not enough.

In Table 3 some organic wastes are given theoretical biogas formation potential. When biogas potential calculations are made, theoretical values are generally used. However, the difference in this study is not based on theoretical values, but on the information obtained from experimental and previous plant data. For this reason, a more realistic biogas formation potential is obtained.

Table 3. Biogas production of some organic wastes.

\begin{tabular}{ccc}
\hline Organic matter type & $\begin{array}{c}\text { Biogas production } \\
\left(\mathrm{m}^{3} / \text { ton }\right)\end{array}$ & References \\
\hline Solid cattle manure & 33 & {$[39]$} \\
\hline Agricultural waste & 20 & {$[40],[41]$} \\
Poultry manure & 78 & {$[39]$} \\
Kitchen waste & 42 & {$[42]$} \\
\hline
\end{tabular}

\subsection{Calculation of theoretical biogas potential of kitchen wastes}

The biomass assumptions and experimental approaches used in the calculations in KTBL Faust Zahlen 2007 [42]:

- $\quad 40 \%$ total solid, $50 \%$ organic total solids.

- Biogas yield: $42 \mathrm{~m}^{3} /$ ton kitchen waste, (59-60\% methane yield). The methane content of the biogas was calculated by multiplying by 0.595 coefficient.

The average methane value per ton of kitchen waste / biofuels is $25 \mathrm{~m}^{3}$.

- The electricity value of $1 \mathrm{~m}^{3}$ of methane is about $4.00 \mathrm{kWh}$ [33] (actual value).

The total biogas potential of kitchen waste was calculated according to Eq (1).

$$
\text { TBPi }=\Sigma \text { AAOMi } x \text { EPi }
$$

Where: TBP is total biogas potential $\left(\mathrm{m}^{3} /\right.$ year); AAOM is annual amount of organic matter ( $\mathrm{t} /$ year); EP is energy potential of waste $\left(\mathrm{m}^{3} /\right.$ ton) (The EP value for the kitchen waste is $25 \mathrm{~m}^{3} /$ ton).

According to Şenol [33] $10 \mathrm{kWh}$ is assumed to equal $1 \mathrm{~m}^{3} \mathrm{CH}_{4}$. The potential to generate electricity from biogas was calculated according to Eq. (2).

$$
\text { e biogas }=\text { E biogas } \mathrm{x} \eta
$$

Where e biogas is the amount of electricity produced in biogas (kWh/year); E biogas is biogas unconverted raw energy in biogas (kWh/year) and electricity of biogas; the quantity may vary depending on the power. In one study, the value of e was equal to $40 \%$ [33]. In this study, this value was determined to be 0.4 .

\section{Results and discussion}

The Table 4 shows the population of each city in the Black Sea region and the daily amount of solid waste per capita. In the 
Samsun region, it is shown that $0.94 \mathrm{~kg}$ of solid waste per person per day while is $0.90 \mathrm{~kg}$ per day in other provinces.

Table 4. Total solid waste amount of provinces in Black Sea region.

\begin{tabular}{ccc}
\hline City & Population & $\begin{array}{c}\text { Amount of kitchen waste per } \\
\text { person (kg/person. day) }\end{array}$ \\
\hline Artvin & 168068 & 0.90 \\
Rize & 331048 & 0.90 \\
Bayburt & 90154 & 0.90 \\
Trabzon & 779379 & 0.90 \\
Giresun & 444467 & 0.90 \\
Ordu & 750588 & 0.90 \\
Gümüşhane & 172034 & 0.90 \\
Tokat & 602662 & 0.90 \\
Amasya & 326351 & 0.90 \\
Çorum & 527863 & 0.90 \\
Sinop & 205478 & 0.90 \\
Kastamonu & 376945 & 0.90 \\
Karabük & 242347 & 0.90 \\
Bartın & 192389 & 0.90 \\
Zonguldak & 597524 & 0.90 \\
Bolu & 299896 & 0.90 \\
Düzce & 370371 & 0.90 \\
Samsun & 1295927 & 0.94 \\
Total & $\mathbf{7 7 7 3 4 9 1}$ & - \\
\hline
\end{tabular}

Table 4 gives the total population of cities in the Black Sea Region, the amount of kitchen waste, the amount of solid waste per capita and the amount of kitchen waste [38].

In Figure 5, kitchen waste quantities are calculated according to some of the Black Sea Region. The highest solid waste was found to belong to Samsun region. According to the calculations, the amount of solid waste generated by the Black Sea Region is approximately 7047.97 tons per day.

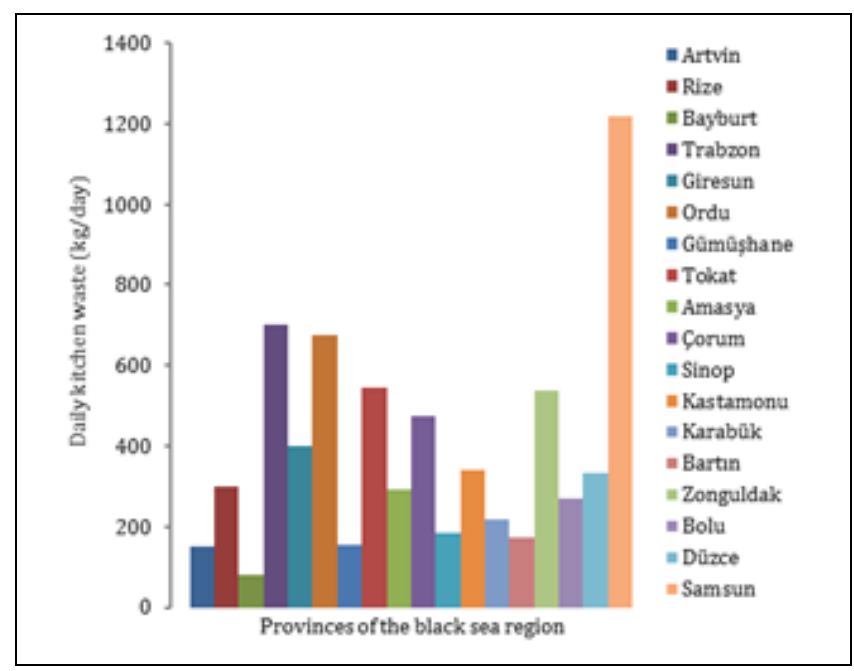

Figure 5. Kitchen waste amount of cities in the Black Sea region ( $\mathrm{kg} /$ day).

As seen in table 4, the solid wastes generated by the countries in the Black Sea Region of our country are calculated on average. Wastes with a total of approximately 7047.97 ton/day affect both global pollution and indirect global warming. The disposal of the wastes in the Black Sea Region is also important in this respect.

The majority of the settlements of the Black Sea Region consist of mountainous terrain. For this reason, the settlements are erratic. This irregularity affects regular solid waste management. For this reason, sometimes the frequency of not collecting garbage can cause air pollution. Besides, these wastes interact with the sea because of the fact that these garbage storage places are not even in the garbage collecting places and the places where they are located are near the sea. This interaction creates air and sea pollution. This is a very bad situation both in terms of human health in coastal areas and in reducing marine biodiversity. For this reason, it is necessary to investigate and improve the methods of disposing of trash in the coastal areas of our country. One of these disposal methods is the biogas plant that will be installed on the garbage fields. There are biogas plants in some of the Black Sea Region, but not enough production is done. The reason for this is the new meeting of our country with the biogas facilities. Methane gas has a global warming of 23 times higher than carbon dioxide over a period of 100 years [39]. This means that 1 metric ton of methane is equivalent to 23 metric tons of carbon dioxide emissions. Therefore, the methane or biogas potential calculated regionally creates awareness for the environment.

Table 5 shows biogas potential and the total daily organic kitchen waste amounts of the Black Sea Region's. As can be seen from the above, a total of 7047.97 tons of kitchen waste per day is formed in the Black Sea Region. The total daily biogas potential that these wastes can produce is $296015.18 \mathrm{~m}^{3}$. $59.5 \%$ of this value is equal to methane gas. This energy value corresponds to the electricity value of $704.52 \mathrm{MWh}$ which can be produced daily.

Figure 6 shows the distribution of methane potentials of the provinces in the Black Sea region. Samsun has the highest methane potential with a rate of $17 \%$. The cities with the highest methane potential after Samsun are Trabzon and Ordu with a rate of $10 \%$.

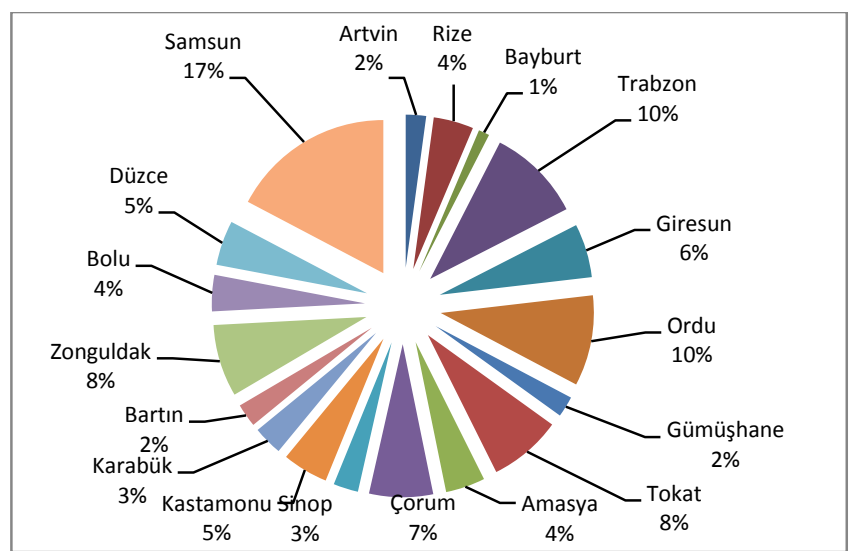

Figure 6. Distribution of annual methane data among cities

Biogas conversion of biomass is in domestic use as well as heat and electricity production by cogeneration technique can be a great economic value. In addition, organic fertilizer is obtained in liquid form as a result of biogas production. The resulting fertilizer can be applied directly to the field as a liquid, granulated or allowed to dry to dry.

The advantage of organic fermentation after fermentation is that most of the pathogenic microorganisms are destroyed as a result of anaerobic fermentation and that the organic fermentation result is $10 \%$ more efficient. Thus, evaluation of kitchen waste by anaerobic biotechnology reduces environmental pollution and promotes environmentally friendly energy production [43]. 
Table 5. Potential biogas potential of kitchen waste from the Black Sea Region.

\begin{tabular}{ccccc}
\hline City & $\begin{array}{c}\text { Amount of organic } \\
\text { waste (ton/day) }\end{array}$ & $\begin{array}{c}\text { Biogas potential } \\
\left(\mathrm{m}^{3} / \text { day }\right)\end{array}$ & $\begin{array}{c}\text { Methane potential } \\
\left(\mathrm{m}^{3} / \text { day }\right)\end{array}$ & $\begin{array}{c}\text { Biogas energy value } \\
(\mathrm{kWh} / \text { day })\end{array}$ \\
\hline Artvin & 151.26 & 6352.97 & 3780.02 & 15120.07 \\
Rize & 297.94 & 12513.61 & 7445.60 & 29782.40 \\
Bayburt & 81.14 & 3407.82 & 2027.65 & 8110.61 \\
Trabzon & 701.44 & 29460.53 & 17529.01 & 70116.05 \\
Giresun & 400.02 & 16800.85 & 9996.51 & 39986.03 \\
Ordu & 675.53 & 28372.23 & 16881.47 & 67525.90 \\
Gümüşhane & 154.83 & 6502.89 & 869.22 & 15476.87 \\
Tokat & 542.40 & 22780.62 & 13554.47 & 54217.88 \\
Amasya & 293.72 & 12336.07 & 7339.96 & 29359.84 \\
Çorum & 475.08 & 19953.22 & 11872.17 & 47488.67 \\
Sinop & 184.93 & 7767.07 & 4621.41 & 18485.62 \\
Kastamonu & 339.25 & 14.248 .52 & 8477.87 & 33911.48 \\
Karabük & 218.11 & 9160.72 & 5450.63 & 21802.51 \\
Bartın & 173.15 & 7272.30 & 4327.02 & 17308.08 \\
Zonguldak & 537.77 & 22586.40 & 13438.91 & 53755.65 \\
Bolu & 269.90 & 11336.07 & 6744.96 & 26979.84 \\
Düzce & 333.33 & 14000.02 & 8330.01 & 33320.06 \\
Samsun & 1218.17 & 51163.20 & 30442.10 & 121768.41 \\
Total & $\mathbf{7 4 4 7 . 9 7}$ & $\mathbf{2 9 6 0 1 5 . 1 8}$ & $\mathbf{1 7 6 1 2 8 . 9 9}$ & $\mathbf{7 0 4 5 1 5 . 9 8}$ \\
\hline
\end{tabular}

Figure 7 shows the annual energy value in MWh by calculating the biogas energy value and methane content generated by the Black Sea Region provinces according to the amount of waste. Provinces with annual energy potential exceeding $15000 \mathrm{MWh}$ were Trabzon, Ordu, Tokat, Çorum, Zonguldak and Samsun. According to these results, energy and cost calculations of biogas plants can be made.

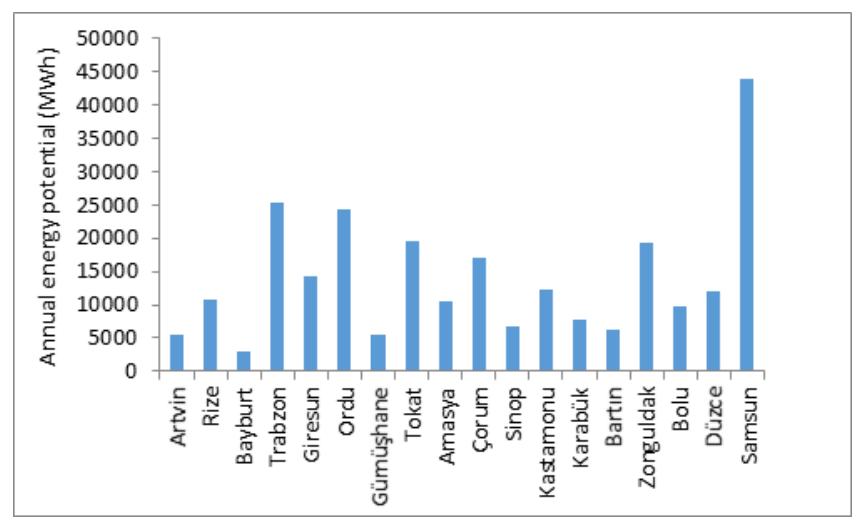

Figure 7. Annual energy value of Black Sea region by provinces.

Studies on Turkey's potential for further calculations were made in different cities [28]. The biogas potential of bovine and ovine fertilizers in Ardahan city was found to be 322.4 $\mathrm{GWh} /$ year. In this study, the biogas potential of the cities in the Black Sea region corresponds to $257 \mathrm{GWh} /$ year. The falling value of daily electricity consumption per capita in Turkey is 2 $791 \mathrm{kWh}$ [44]. Considering this value, the calculated biogas potentials provide a significant saving.

\section{Conclusions and recommendations}

Biogas energy has a very important place in terms of our country. Biogas can't cover all of our energy needs, but it allows us to save a lot of energy. Our country has a very rich value in terms of biogas production potential. In this article, the contribution to biogas potential and energy saving which can be formed from kitchen waste of Black Sea Region was calculated.

The region that is experiencing the biggest garbage storage areas in our country is the Black Sea Region. As the geographical position of settlements in the Black Sea Region, the mountains extend parallel to the sea. For this reason, the level of land is very small. Kitchen wastes emerging in the Black Sea Region are carried to garbage fields and pollute the environment. This causes the storage areas of the garbage to be insufficient and the storage of the garbage to occur. Due to the growing population in our country, the amount of garbage is also increasing. For this reason, the storage areas of garbage will increase in the coming years. So it is inevitable that the garbage will be poured into the sea. Even in the Black Sea Region some of the garbage is poured into the sea. This situation causes a great environmental pollution. For this reason, this garbage should definitely be recycled and disposed of.

The best way to dispose of organic wastes from garbage is to produce biogas by anaerobic fermentation. As a result of this production, organic fertilizer is formed as a by-product. This proves that the garbage has become useful to us.

From an economic point of view, biogas requires a high initial cost and is therefore an expensive alternative energy source. The small-scale biogas plant can pay off for 8-10 months when it is operated efficiently [45]. However, one study found that a large biogas plant working with cattle manure pays for itself in 5 years [46]. In this article, the biogas value of organic solid wastes of each of the Black Sea Region's illicit sources has been determined. From these values, province Samsun, which has the highest potential of biogas, and Bayburt, which has the least biogas potential were found. The total energy potential of the Black Sea Region, which can only be produced from organic wastes, is $70451598 \mathrm{kWh} /$ day. It is accepted that the value of $1 \mathrm{kWh}$ is approximately $0.53 \mathrm{TL}$ [47]. If all of the kitchen wastes in the Black Sea Region are evaluated, daily income is 373393 billon TL. This value is very important in the waste assessment policy. However, financing is needed above all to establish the 
plant. This fund can be provided with state-funded loans. In many countries, programs have been launched considering the environmental and health benefits of biogas technology. Incentives and credits can apply to reduce costs and expand biogas systems.

Turkey's energy potential of biomass; 120 Mtoe (Million Tonnes of oil Equivalent) as natural capacity, 50 Mtoe as technical capacity and 32 Mtoe as economic potential [48]. Biomass energy supply including wastes has been 7208 ktoe (thousand tonnes of oil equivalent) in 1990, 7068 ktoe in 1995 and 6457 ktoe in 2000 [49]. Available in classic and modern biomass energy production in Turkey is planned in 2010 to around 7414 ktoe. This value for 2020 is 7520 ktoe and for 2 030 is 8205 ktoe [48]. This suggests that an important source of biomass energy plants in Turkey. Considering the climatic conditions and production facilities; low investment costs, high efficiency and easy installation, operation and maintenance for the design of biogas systems will enable the development of biogas technology in Turkey.

Turkey's rapid growth has also brought with it the energy needs of the population. Turkey is required to determine the potential of renewable energy before if there is this need to turn to renewable energy. Turkey must first determine renewable energy sources to increase the use of renewable energy sources. For this, the energy potential of regions and cities should be determined. A feasibility report is prepared for biogas energy potentials which are one of the renewable energy sources. A biogas production facility is established if the potential energy costs are higher. In this study, biogas potential calculation of kitchen wastes in the Black Sea region was performed. Thus, a resource was created for the feasibility reports to be prepared for plant installation.

\section{References}

[1] Ardıç İ. Investigation of the Effects of Thermal, Chemical and Thermochemical Pretreatments on the Biogas Production Efficiency from Chicken Manure. MSc Thesis, Mersin University, Mersin, Turkey, 2003.

[2] Kobya M. Biogas Production from Cattle Manure and Design of a Biogas Facility for Erzurum Conditions. MSc Thesis, Ataturk University, Erzurum, Turkey, 1992.

[3] Avcioğlu 0, Türker U. "Status and potential of biogas energy from animal wastes in Turkey". Renewable and Sustainable Energy Reviews, 16, 1557-1561, 2012.

[4] Liu C, Huan Li, Zhang Y, Liu C. "Improve biogas production from low-organic-content sludge through high-solids anaerobic co-digestion with food waste". Bioresource Technology, 219, 252-260, 2016.

[5] Moukazis I, Pellera F.M, Gidarakos E. "Slaughterhouse by-products treatment using anaerobic digestion". Waste Management, 71, 652-662, 2018.

[6] Şenol H, Elibol EA, Açıkel Ü, Şenol M. "Major organic waste sources in Ankara for biogas production". BEU Journal of Science, 6(2), 15-28, 2017.

[7] Ware A, Power N. "Biogas from cattle slaughterhouse waste: Energy recovery towards an energy self-sufficient industry in Ireland". Renewable Energy, 97, 541-549, 2016.

[8] Haak L, Roy R, Pagilla K. “Toxicity and biogas production potential of refinery waste sludge for anaerobic digestion". Chemosphere, 144, 1170-1176, 2015.
[9] Çağlayan GH, Koçer NN. "Evaluation of the potential of livestock breeding in the city of Mus for the research of biogas production". Mus Alparslan University Science Journal, 2(1), 215-220, 2014.

[10] Moukazis I, Pellera FM, Gidarakos E. "Slaughterhouse byproducts treatment using anaerobic digestion". Waste Management, 71, 652-662, 2018.

[11] Bayrak EH. Investigating the Effects of Pretreatment in the Conversion of Wet Sludge From Urban Sources and/or Fruit Juice Wastewater Treatment Plants Into Biogas, Phd Thesis, Cumhuriyet University, Sivas, Turkey, 2014.

[12] Afacan H. Determination of Working Conditions of a Biogas Plant with Small Scale Continuous Feeding, Master's Thesis, Gaziosmanpasa University, Tokat, Turkey, 2008.

[13] Alçiçek A, Demiruluş H. "Use of farm fertilizers in biogas technology". Ecology Environment journal, 13, 5-9, 1994.

[14] Jingquing Y, Dong L, Yongming S, Guohui W, Zhenhong Y, Feng Z, Yao W. "Improved biogas production from rice straw by co-digestion it kitchen and pig manure". Waste Management, 33, 2653-2658, 2013.

[15] T.C. Ministry of Energy and Natural Resources. "Biogas". http://www.yegm.gov.tr/yenilenebilir/biyogaz.aspx (05.02.2018).

[16] Solera R, Romero LI, Sales D. “ The evolution of biomass in a two-phase anaerobic treatment process during startup". Biochemical Engineering Journal, 16(1), 25-29, 2002.

[17] Stuckey D.C. "The effect of heat and additives on anaerobic digestion in developing countries". International Biogas Conference, Ankara, Turkey, 23-26 November, 1981.

[18] Pullammanappallil PC, Chynoweth DP, Lyberatos G, Svoronos S.A. "Stable performance of anaerobic digestion in the presence of a high concentration of propionic acid". Bioresource Technology, 78(2), 165-169, 2001.

[19] İlkılıç $\mathrm{CH}$, Deviren $\mathrm{H}$. "Formation of Biogas and Purification Methods of Biogas". $6^{\text {th }}$ International Advanced Technologies Symposium (IATS'11), Elazığ, Turkey, 16-18 May 2011.

[20] Li L, Kiran E. "Interaction of supercritical fluids with lignocellulosic materials". Industrial \& Engineering Chemistry Research, 27 (7), 1301-1312, 1988.

[21] Wikandari R, Nguyen H, Millati R, Niklasson C, Taherzadeh MJ. "Improvement of biogas production from orange peel waste by leaching of limonene". Biomed Research International, 15, 1-6, 2015.

[22] Singh R, Shukla A, Tiwari S, Srivastava M. "A review on delignification of lignocellulosic biomass for enhancement of ethanol production potential". Renewable Sustainable Energy Reviev, 32, 713-728, 2014.

[23] Göğüș A.Y. "İște Biyogaz". Journal of Heat Science and Technology, 9(4), 42-44, 1986.

[24] Hendriks ATWM, Zeeman G. "Pretreatments to enhance the digestibility of lignocellulosic biomass". Bioresource Technology, 100(1), 10-18, 2009.

[25] Dino IG, Akgül CM. "Impact of climate change on the existing residential building stock in Turkey: An analysis on energy use, greenhouse gas emissions and occupant comfort". Renewable Energy, 141, 828-846, 2019.

[26] Koçar G, Eryaşar A, Ersöz Ö, Arıcı Ş, Durmuş A. Biyogaz Technologies, $2^{\text {nd }}$ ed. İzmir, Turkey, Ege University Press, 2010. 
[27] Kaygusuz K. "Renewable and sustainable energy use in Turkey: a review". Renewable and Sustainable Energy Reviews, 6(4), 339-66, 2002.

[28] Ozer B. "Biogas energy opportunity of Ardahan city of Turkey". Energy, 139(1), 1144-1152, 2017.

[29] Ozcan M, Oztürk S, Oguz Y. "Potential evaluation of biomass-based energy sources for Turkey". Engineering Science and Technology, 18(1), 178-184. 2015.

[30] Erdil A, Erbiyık H. "Renewable energy sources of Turkey and assessment of sustainability". Procedia-Social and Behavioral Sciences, 207, 669-679, 2015.

[31] Ozturk M, Yuksel YE. "Energy structure of Turkey for sustainable development". Renewable and Sustainable Energy Reviews, 53, 1259-1272, 2016.

[32] Salihoglu G, Salihoglu NK, Ucaroglu S. Banar M. "Food loss and waste management in Turkey". Bioresource Technology, 248, 88-99, 2018.

[33] Şenol H. "Biogas potential of hazelnut shells and hazelnut wastes in Giresun City". Biotechnology Reports, 24, 1-6, 2019.

[34] Karaca C, Gurdil G. Biogas Production Potential from Animal Manure in Samsun Province of Turkey, Scientia Agriculturae Bohemica, 50(2), 135-140, 2019.

[35] Göktaş H, Kocabey S, Özdemir Z. "Investigation of biogas energy potential in Kirklareli province". $8^{\text {th }}$ International Ege Energy Syposium, Afyonkarahisar, Turkey, 11-13 May 2016.

[36] Öztürk B, Kilickan A. "Determination of biogas potential of Aydın province, scientific papers-series". Agronomy, 59, 531-536, 2016.

[37] Kitchen Waste. "Mutfak Atıklarından Biyogaz". https://www.google.com.tr/search?q=mutfak+at $\% C 4 \% B$ 1 klar\%C 4\%B1ndan+biyogaz\&tbm=isch\&tbo=u\&source= univ\&sa $=X \& v e d=0$ ahUKEwjRxvXkYjUAhVFIpoKHZniBwMQsAQIUQ\#imgrc=ZDnItl8Ppol-M, (15.04.2018).

[38] T.C. Ministry of Environment and Urban Planning. "Türkiye'de Atıklardan Enerji Üretimi ve Biyogaz". http://www.tarimsal.com/makaleler/Turkiye_Atiklarda n_Enerji_uretimi_ve_biyogaz.htm (15.03.2018).

[39] Chu H, Hosen Y, Yagi K. "NO, N2O, CH4 and CO2 fluxes in winter barley field of Japanese Andisol as affected by $\mathrm{N}$ fertilizer management". Soil Biology and Biochemistry, 39, 330-9. 2007.
[40] Biogas yields. "Solea Energy". http://www.soleaenerji.com/biyogaz-verimi/ (15.03.2018).

[41] Aybek A, Üçok S, Bilgili ME, Ali İspir M. “Determination of biogas energy potential of some agricultural wastes in kahramanmaraş province". The Journal of Agricultural Faculty of Uludag University, 29(2), 25-37. 2015.

[42] Agrahari RP, Tiwari GN. "The production of biogas using kitchen waste". International Journal of Energy Science, 3(6), 408-15, 2013.

[43] Li Y, Jin Y, Jinhui Li, Li H, Yu Z, Nie Y. "Effects of thermal pretreatment on degradation kinetics of organics during kitchen waste anaerobic digestion". Energy, 118, 377- 386, 2017.

[44] TMMOB Makine Mühendislieri Odası. “Türkiye'nin Enerji Görünümü". http://www1.mmo.org.tr/resimler/dosya_ekler/c37b2d c6484b7db_ek.pdf, (09.12.2019).

[45] Deng L, Liu Y, Zheng D, Wang L, Pu X, Song L, Wang Z, Lei Y, Chen Z, Long Y. "Application and development of biogas technology for the treatment of waste in China". Renewable and Sustainable Energy Reviews. 1(70), 845-851, 2017.

[46] Eryaşar A. Design, Manufacture, Trial Run and Investigation of Parameters Impacting its Performance of a Biogas System for Rural Use. Phd Thesis. Ege University, Izmir, Turkey, 2007.

[47] Energy Institute. "How is the Electricity Bill Calculated?" http://enerjienstitusu.de/elektrik-fiyatlari/ (15.10.2019).

[48] Toklu E, Güney MS, Omaklı O, Kaygusuz K. “Energy production, consumption, plocies and recent developments in Turkey". Renewable and Sustainable Energy Reviews, 4(11), 72-86. 2010.

[49] Özyurt 0. "Energy issues and renewables for sustainable development in Turkey". Renewable and Sustainable Energy Reviews, 14(29), 76-85, 2010. 